\title{
Efficient microbubble- and ultrasound-mediated plasmid DNA delivery into a specific rat liver lobe via a targeted injection and acoustic exposure using a novel ultrasound system
}

\author{
Shuxian Song ${ }^{\dagger}$, Misty Noble $^{\dagger}$, Samuel Sun ${ }^{\dagger}$, Liping Chen ${ }^{\dagger}$, Andrew A. Brayman ${ }^{\ddagger}$, and Carol \\ H. Miao ${ }^{\star}, \dagger, \ddagger, \S$ \\ †Seattle Children's Research Institute, Seattle, WA \\ ${ }^{\ddagger}$ Center for Industrial and Medical Ultrasound, Applied Physics Laboratory, University of \\ Washington, Seattle, WA \\ $\S$ Department of Pediatrics, University of Washington, Seattle, WA
}

\section{Abstract}

To develop efficient gene delivery in larger animals, based on a previous mouse study, we explored the luciferase reporter gene transfer in rats by establishing a novel unfocused ultrasound system with simultaneous targeted injection of a plasmid and microbubble mixture into a specific liver lobe through a portal vein branch. Luciferase expression was significantly enhanced over 0 $30 \mathrm{Vol} \%$ of the Definity ${ }^{\circledR}$ microbubbles, with a plateau between 0.5 and $30 \mathrm{Vol} \%$. The increase of gene delivery efficiency also depended on the acoustic peak negative pressure, achieving over 100 -fold enhancement at 2.5 MPa compared with plasmid only controls. Transient, modest liver damage following treatment was assessed by transaminase assays and histology, both of which correlated with gene expression induced by acoustic cavitation. In addition, pulse-train ultrasound exposures (i.e., with relatively long quiescent periods between groups of pulses to allow tissue refill with microbubbles) produced gene expression levels comparable to the standard US exposure but reduced the extent of liver damage. These results indicated that unfocused high intensity therapeutic ultrasound exposure with microbubbles is highly promising for safe and efficient gene delivery into the liver of rats or larger animals.

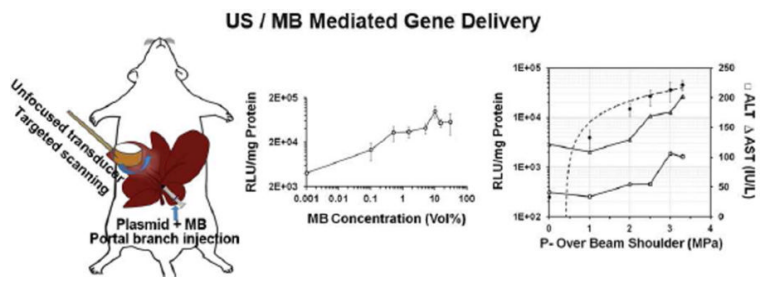

\footnotetext{
*Corresponding Author. Carol H. Miao, Ph.D., Department of Pediatrics, Seattle Children's Research Institute, and University of Washington, 1900 Ninth Avenue, Seattle, WA 98101. Phone: 206-884-7316; Fax: 206-987-7310; miao@u.washington.edu. SUPPORTING INFORMATION

Table SI1. Alanine transaminase (ALT) and aspartate transaminase (AST) of plasma collected from rats treated with acoustic pulses involving various inter-pulse periods (IPP).

Table SI2. Alanine transaminase (ALT) and aspartate transaminase (AST) of plasma collected from rats treated with various pulsetrain US exposure regimens.

Table SI3. The extents of hepatic necrosis damage on day 1 from variable treatments.

Table SI4. Summary of various animal experiments.

This material is available free of charge via the Internet at http://pubs.acs.org.
} 


\section{Keywords}

ultrasound-targeted microbubble destruction technique; non-viral gene delivery; acoustic cavitation; ultrasound-induced bioeffects; vascular and cellular permeabilization

\section{INTRODUCTION}

The liver is an attractive organ for targeted gene therapies to attack numerous diseases ${ }^{1,2}$, as it plays an important role in metabolic pathways and the production of serum proteins. There has been great progress in developing viral vectors for liver-directed therapy in vivo ${ }^{2-4}$. However, there remain substantive hindrances to the clinical application of viral gene delivery ${ }^{5-7}$. Non-viral delivery methods have received much focus alternatively due to the higher gene carrying capacity, lower immunogenicity, and diversity and ease of vector construction ${ }^{8}$.

Therapeutic ultrasound (US) has been explored widely in vitro ${ }^{9-11}$ and in vivo ${ }^{12-16}$ as a tool with which to increase gene or drug delivery. In the presence of ultrasound contrast agents, which are almost always microbubbles (MBs), sonoporation ${ }^{17,} 18$ can induce small-scale tissue hemorrhage which permits delivery of molecules from ruptured microvessels into the extravascular space of surrounding tissues. However, for relatively large molecules, transport across the blood vessel wall can be enhanced by US treatments which are insufficient to cause red cell extravasation, indicating that vascular permeabilization can be more subtle than microvessel ruptures which permit the escape of particles several microns in diameter ${ }^{19}$. Plasma membrane permeability can also be modified by US and MBs via the formation of transient, non-lethal perforations on the cell membrane induced by MB dynamical responses to $\mathrm{US}^{20-24}$.

Ultrasound targeted MB destruction techniques have been applied to the problem of delivering 'difficult' molecules from the vasculature to tissues of interest in a selective way ${ }^{25}$. Three areas have attracted the most attention with respect to US-enhanced drug or non-viral gene delivery: (1) tumor ${ }^{15,26-28}$, (2) cardiovascular ${ }^{29-33}$, and (3) skeletal muscle treatment ${ }^{34-37}$. Gene transfection efficiency enhancement produced by UTMD depends on a variety of variables, such as the particulars of the physical acoustics (see, e.g., ${ }^{38-40}$ ), and the types or concentrations of contrast agents used ${ }^{41,42}$. Furthermore, some treatment strategies using US exposure combined with viral- ${ }^{43}$ or non-viral carriers ${ }^{44}$, 45 , or combined with other physical methods ${ }^{46}$ have produced significant enhancements of transgene expression.

In two of our previous studies, a focused US system and Definity ${ }^{\circledR}$ ultrasound contrast agent successfully enhanced gene transfer efficiency in mouse liver by intra-hepatic or intra-portal injection ${ }^{47-49}$. The dominant mechanism appears to have been inertial acoustic cavitation. However, when this delivery system was applied to treat rat livers, there was only a modest increase of gene expression. Contemplating the possible causes for the disparate results obtained with mice and in early studies with rats, we arrived at the following hypotheses: (1) Due to the small focal 'spot' ( $\sim 3 \mathrm{~mm}$ in diameter) of the focused transducer system we had been using, the effective exposure of the much larger rat liver within the plasmid and MB injection period might be limiting, despite use of mechanical scanning to move the focus about in the rat liver; (2) There are biochemical and histological differences between rat and mouse liver, which might lead to different effects produced by US/MB interactions with tissues, and thus different transgene efficiencies. Since MB and US-induced extravasation events have been observed in a wide variety of tissues, we believed that hypothesis (1) was the most likely cause of the relatively poor results we had obtained in preliminary studies with rats. Accordingly, we undertook development of a therapeutic US transducer whose 
effective beam dimensions better 'fit' the rat liver, and to optimize the US/MBs parameters and gene transfer protocols to scale up US/MB mediated gene delivery from the murine model to application in the much larger rat liver. The data principally supported hypothesis (1). The gene transfer efficiencies we observed, together with minimal liver damage indicated that this delivery system is promising for gene therapeutic exploration in the rat hepatic model.

\section{EXPERIMENTAL SECTION}

\section{Plasmids}

The luciferase reporter plasmid pGL4.13 [luc2/SV40] (Promega) was produced by GenScript Inc. (Piscataway, NJ, USA) according to standard techniques. In all gene transfer experiments, $150 \mu \mathrm{g}$ plasmids per rat were used.

\section{Ultrasound systems}

In most of experiments, the acoustic treatment system was comprised of a combination pulse generator/high power radio frequency pulse amplifier capable of generating up to 1000 Watts of electrical power into a $50 \Omega$ load (Model RFG-1000; JJ\&A Instruments, Duvall, WA), driving a purpose-designed $16 \mathrm{~mm}$ diameter planar transducer and impedance matching network (Model H158A; Sonic Concepts, Bothell, WA). In the experiment exploring gene delivery mediated by acoustic exposure with longer pulse duration, the same transducer was driven by an Agilent Model 33120A arbitrary function generator and an ENI AP400B amplifier (Electronic Navigation Systems, Rochester, NY).

The acoustic treatment of the liver was performed by applying the transducer directly to the surface of the surgically-exposed liver, using a small amount of commercial diagnostic ultrasound gel to couple the transducer to the liver.

\section{Microbubbles}

Definity® (Lantheus Medical Imaging, Massachusetts, USA) is a lipid-shelled contrast agent comprised of encapsulated octafluoropropane gas, with a maximum concentration of $1.2 \times 10^{10} \mathrm{bubbles} / \mathrm{ml}$ and a mean diameter range of 1.1 to $3.3 \mu \mathrm{m}$. Definity ${ }^{\circledR} \mathrm{MBs}$ were generated by shaking a vial for $45 \mathrm{sec}$ with a Vialmix ${ }^{\circledR}$ (Lantheus Medical Imaging, Massachusetts, USA) before being mixed with plasmids in PBS. For all experiments, final Definity concentrations are expressed as volume percentages ((ml stock Definity/final volume) $\times 100 \%)$.

\section{Animals}

Six-week-old SAS SD male rats were purchased from Charles River Laboratories International, Inc. (Wilmington, MA, USA) and maintained at a specific pathogen-free (SPF) vivarium for at least 3 days before the experiments. All animal experiments were carried out under local IACUC-approved protocol in accordance with the guidelines for animal care of both National Institutes of Health and Seattle Children's Research Institute.

\section{Targeted gene delivery by US exposure with MBs}

Prior to surgery and during treatments, rats were anesthetized by continuous inhalation of isoflurane, and recovered within $1 \mathrm{~h}$ after surgery. A midline incision was made to expose the rat liver. The right section (the larger part) of the medial lobe was flipped over to expose the major vessels on the dorsal surface. In all experiments, $150 \mu \mathrm{g}$ of plasmid DNA per rat was used as a standard dosage. Definity ${ }^{\circledR}$ MBs were activated by shaking the Definity ${ }^{\circledR}$ solution vial for $45 \mathrm{sec}$. Immediately before injection, desired volumes of MBs were 
withdrawn with a glass microsyringe and slowly added into plasmid solution (dissolved in PBS containing 5\% glucose) with gentle mixing. For each rat, about $1 \mathrm{ml}$ total volume of plasmid and MB mixture was injected into the target liver lobe using a 24-G catheter via a specific portal vein branch which supplies the right part of the medial lobe. More specifically, the catheter was inserted into a portal vein branch supplying the targeted lobe, and was connected with a plasmid/MB filled syringe. The injection rate was slow $(\sim 20 \mu \mathrm{l} / \mathrm{s})$, intravascular pressure was not elevated significantly by the injection. The duration of the injection was $45 \mathrm{~s}$ with simultaneous acoustic exposure and a follow-on exposure of $45 \mathrm{~s}$, for a total exposure duration of $90 \mathrm{sec}$. With immediate hemostasis and suturing, the rats recovered from anesthesia and lived with low apparent morbidity until the animals were sacrificed for liver harvest. Blood samples were collected by cardiac puncture immediately before animal sacrifice, and were used to assess liver damage by transaminase assay (see below).

\section{Histological assessments of livers harvested over a 30-day post-treatment period}

In order to reveal the liver damages and subsequent repair induced by various treatments, after the injection of plasma DNA + different concentrations of MB along with or without US exposure, all the liver tissues were harvested immediately or at day $1,5,12,30$. The tissues were fixed in $10 \%$ neutral buffered formalin, embedded in paraffin, and sections were stained with hematoxylin and eosin (H\&E) for histological examination. Stained tissue samples were evaluated by an experienced pathologist.

\section{Evaluation of luciferase gene expression}

To analyze luciferase gene expression in the treated liver, the right section of the median lobe was harvested at $24 \mathrm{~h}$ after gene delivery and homogenized in reporter lysis $1 \times$ buffer (Promega, Madison, WI, USA) at a ratio of $3 \mathrm{ml} / \mathrm{g}$ liver.

The homogenate was frozen and thawed three times and then centrifuged $(18000 \mathrm{~g} \times 5 \mathrm{~min})$ to recover the supernatant for measurement. Luciferase activity was measured by using a commercial kit (Luciferase Assay System, Promega, Madison, WI, USA) and a luminometer (Victor 3; Perkin Elmer, Wellesley, MA, USA). The luciferase expression data are expressed as relative light units per $\mathrm{mg}$ protein (RLU/mg protein).

\section{Transaminase assay}

Blood samples were collected from treated mice immediately or on day 1, 5, 12, 30 after gene delivery for the transaminase assay. Alanine aminotransferase (ALT or SGPT) and aspartate aminotransferase (AST or SGOT) levels were determined by using commercial assay regents (Teco Diagnostics, Anaheim, CA, USA). Normal, untreated rats were used as controls.

\section{Statistical analysis}

All data are presented as means \pm SEM. Student's t-test was used to determine statistical significance for independent samples. Data were considered significant when the p-value was $\leq 0.05$.

\section{RESULTS}

\section{Design and characteristics of a transducer suitable for gene transfer into the rat liver}

We believed that for effective treatment of the rat liver, which is substantially larger than the mouse liver, a transducer with a larger acoustic beam area was needed. Thus, H158A transducer ( 16mm diameter, Table 1) was built, replacing the focused transducer used for 
mice, the latter having a focal diameter (full width, half maximum) of only $\sim 3 \mathrm{~mm}$. The H158A transducer can generate a maximum of 2.5-3 MPa pressure amplitudes across most of the transducer face. Axial pressure profiles along the beam centerline as measured by a hydrophone showed a series of maxima and minima (Figure 1a), indicating that there is substantial variation in acoustic pressure along the acoustic axis, and that any single-value pressure estimator will fail to capture the complexity of the pressure field experienced by tissues along the acoustic path. The transaxial acoustic pressure profile (Figure 1b) is also structured with a series of maxima and minima with a sharp roll-off at the beam edge. Within this region, the difference between the highest peaks and the lowest valleys is $\sim 6 \mathrm{~dB}$. When used in the gene transfer experiments, the transducer was scanned slowly over the liver to more evenly distribute the acoustic exposure. The spatial average normalized pressure amplitude within the half maximum, full width beam diameter was used as a reference value for transducer output calibrations.

\section{Comparison of gene delivery effect with new US system vs. with focused US system}

The efficiency of gene delivery into the rat liver was examined using the new US system (frequency $=1.1 \mathrm{MHz}$, pulse width $=20$ cycles, pulse repetition frequency $=13.9 \mathrm{~Hz}$, and peak negative acoustic pressure $=2.7 \mathrm{MPa}$ ). In addition, the delivery route was modified from the general portal injection we used previously in mice, to a targeted injection toward a specific liver lobe (median lobe) through the portal vein branch in $45 \mathrm{sec}$. Similarly, the US exposure $(90 \mathrm{sec}$ ) also focused on the target lobe instead of the whole liver. For comparison, gene delivery was also performed using the old focused system to treat the whole liver (frequency $=1.17 \mathrm{MHz}$, pulse width $=20$ cycles, pulse repetition frequency $=50 \mathrm{~Hz}$, and peak negative acoustic pressure $=3 \mathrm{MPa}$ ).

The enhancements of the gene transfer efficiency (ratio of gene expression of US treated rats vs. plasmid injected rats without US treatment) produced by different US treatment were shown in Figure 2. The enhancement of transgene expression using focused transducer driven by ENI AP400B amplifier was only $\sim 3$ fold, while the targeted-lobe treatment with unfocused transducer driven by either ENI AP400B or RFG-1000 amplifier achieved over 200 fold enhancement. The ENI AP400B can generate longer pulse duration as shown in our previous studies, while the RFG-1000 used in this study can generate higher peak negative pressure; both of which are used for further studies on different optimization experiments. Based on these results, targeted treatment of a specific liver lobe using the new unfocused transducer and injection method was used in all following studies.

\section{Effect of US exposure and Definity MBs on gene delivery via portal branch injection}

Rats were treated respectively in the presence or absence of MBs and with or without US in 4 groups: $\{$ plasmid only $\},\{$ plasmid + MBs $\},\{$ plasmid + US $\}$, and $\{$ plasmid + MBs + US $\}$. As shown in Figure 3, luciferase expression in the \{plasmid only and \{plasmid $+\mathrm{MB}$ \} groups showed low baseline levels (200-300 RLU/mg protein). US exposure at $2.7 \mathrm{MPa}$ produced a significant increase in luciferase expression even without MBs, which was about 15 -fold $\left(3.63 \pm 0.96 \times 10^{3} \mathrm{RLU} / \mathrm{mg}\right.$ protein) greater than in the negative control. Further dramatic enhancement was achieved in the \{plasmid $+\mathrm{MB}+\mathrm{US}\}$ treatment group $(9.2 \pm 1.6$ $\times 10^{4} \mathrm{RLU} / \mathrm{mg}$ protein, $\sim 350$ fold vs. \{plasmid only\}, $\sim 25$ fold vs. \{plasmid $\left.+\mathrm{US}\right\}$ ). Thus US can significantly increase plasmid transfer efficiency and together with MBs can further improve the gene transfer.

\section{Gene delivery mediated by US with varying MB concentrations}

Definity® MBs in the range from 0-30 Vol\% with plasmid pGL4 were delivered through a portal branch. The US source was the unfocused H158A transducer producing 'positive control' exposure conditions (1.1 MHz, 20 cycle pulses, $13.9 \mathrm{~Hz}$ PRF, and 2.7 MPa PNP). 
MBs added to the plasmid solution produced a significant enhancement on plasmid delivery efficiency with US exposure (Figure 4). In \{plasmid + MB + US \} treatments where MB concentration was $0.5 \mathrm{Vol} \%$, rats showed eight-fold increment in gene expression (vs. \{plasmid + US \}). Luciferase expression plateaued at MBs concentrations between 0.5-30 Vol\%. A local maximum in gene expression was associated with an MB concentration of 10 Vol\% $\left(9.9 \pm 3.0 \times 10^{4}\right.$ RLU/mg protein $)$.

\section{Gene transfer efficiency upon various US peak negative pressures (PNP)}

US exposures at various PNPs (0-3.3 MPa) were performed using the $\mathrm{H} 158$ transducer. Total treatment time was $90 \mathrm{sec}$, using 20 cycle pulses and a pulse repetition frequency (PRF) of $12.5 \mathrm{~Hz}$. The medial lobe of the rat liver was injected with $150 \mu \mathrm{g}$ pGL4 plasmid and $15 \mathrm{Vol} \%$ Definity® MBs via a portal vein branch. Gene expression and transaminase levels are plotted as functions of spatial average acoustic pressure. Luciferase expression increased rapidly with increasing acoustic pressure over the range of 0 to $2.0 \mathrm{MPa}$, followed a gradual plateau in expression level (Figure 5). Liver damage associated with US treatment was assessed by transaminase levels (ALT or AST) at $24 \mathrm{hr}$ after treatment (Figure 5). At lower pressures (0-2.5 MPa), ALT values of US treated rats were similar to those of US negative control rats $(\sim 50 \mathrm{IU} / \mathrm{L})$. Similarly, AST values remained at nominal control levels ( 100 IU/L) until the acoustic pressure exceeded 2.0 MPa. In the 0-2.0 MPa range, gene expression increased rapidly without increasing liver damage. Exposure at 2.5 MPa PNP produced $>100$ fold of luciferase expression compared US untreated control $\left(2.6 \pm 0.9 \times 10^{4}\right.$ vs. $245 \pm 134 \mathrm{RLU} / \mathrm{mg}$ Protein). At 2.5-3.3 MPa, liver damage (i.e., ALT or AST levels) increased without much gain in gene expression levels.

\section{Effect of inter-pulse period or pulse train US exposure on gene transfer efficiency}

It was hypothesized that longer quiescent periods between acoustic exposure pulses would enable reperfusion of the liver tissues with MBs and plasmid following MB-destroying acoustic exposures to achieve more sustained tissue distribution, and would thus increase gene delivery efficacy. The H158 planar transducer was again used. However, to generate longer inter-pulse periods (IPP), our 'standard' US conditions were modified to 72-4000 ms IPP, with corresponding pulse durations ranging from 18 1000 $\mu$ s (Table 2 upper panel). All groups were treated by a 45 -sec injection of plasmid pGL4 containing $10 \mathrm{Vol} \% \mathrm{MBs}$, with a total US exposure of $90 \mathrm{~s}$, the first $45 \mathrm{sec}$ being coincident with the injection. The luciferase expression data showed no enhancement by using longer IPP (Figure 6a), moreover, transaminase levels increased compared with our 'standard' exposure conditions (Table SI1), indicating that the US procedure with longer pulse durations induced more liver damage.

An alternate strategy to produce longer quiescent periods between US bursts was subsequently used. The PNP was $2.7 \mathrm{MPa}$. Pulse lengths were 20 cycles (18 $\mu$ s) and were repeated at either 14 or $56 \mathrm{~Hz}$ pulse repetition frequency while the US was 'on', which was either 'continuously' for the entire treatment period, or for 1 or $2 \mathrm{sec}$ periods interrupted by quiescent intervals of up to $3 \mathrm{sec}$. The total exposure duration was $90 \mathrm{sec}$, with coincident portal branch injection of plasmid pGL4 and $10 \mathrm{Vol} \% \mathrm{MBs}$ for $45 \mathrm{sec}$ or $90 \mathrm{sec}$. The acoustic parameters are shown in Table 2 (lower panel). As shown in Figure 6b, compared with the positive control $\left(8.2 \pm 0.9 \times 10^{4} \mathrm{RLU} / \mathrm{mg}\right.$ protein; 'continuous' pulsed exposure), transgene expressions in the groups with 'on' times of $1 \mathrm{sec}$ or $3 \mathrm{sec}$ and an 'off' time of 2 sec at PRF $13.9 \mathrm{~Hz}$ were comparable, even though the interrupted US exposure groups were reduced to $30-60 \%$ of total acoustic exposure. Transaminase data (Table SI2) indicates a preliminary trend of liver damage, which was decreased with reduction of total acoustic exposure. At higher PRF (56 Hz), the groups with an 'on' time of $1 \mathrm{sec}$ or $2 \mathrm{sec}$ and 'off' time of $2 \mathrm{sec}$ showed higher gene expression compared with the continuously US-treated 
control. However, the treated groups at higher PRF had higher transaminase levels compared with those treated at lower PRF due to higher total US exposure.

\section{Histological assay for liver damage}

The extent of liver damage in rats treated with various acoustic PNP (0-3.3 MPa) and MB concentrations $(0-10 \mathrm{Vol} \%)$ were determined by H\&E staining. Tissue samples were taken on day 0 (right after treatment), 1, 5, 12 or 30 after treatment. Sections of normal liver lobe were examined as controls (data not show). The extents of hepatic damage in sections was variable, thus the selected results shown in Figure 7 are intended to demonstrate the types of tissue damage and represent areas of maximum hepatic injury; i.e., they are not typical representations of tissue damage because there was no apparent damage on most of the treated liver lobe.

All histologic sections taken immediately after treatment only showed minor or some hemorrhage (Figure 7a, f). In the sections treated with both MBs and US, there were numerous macro- $(>10 \mu \mathrm{m}$ in diameter) and micro-vesicles $(<10 \mu \mathrm{m})$ in the sinusoids (Figure 7a insert). Healthy hepatocytes could be found around the central vein. A few Kupffer cell nuclei could be identified around those macro-vesicle filled sinusoids.

On day 1, sections from \{plasmid only \} or \{plasmid $+\mathrm{MB}$ \} treated liver showed minor hemorrhages, with retention of normal lobular structure (Figure 7g). The sinusoids were dilated with clear Kupffer cells along them. There was no evidence of coagulative necrosis. This indicates that a low level of hepatic pathologic changes was induced by the injection procedure. In sections from tissues treated with US, lobular structure was in general mostly normal, but in contrast to the \{plasmid only $\}$ or $\{$ plasmid $+M B\}$, there were several sharply demarcated regions of coagulative necrosis (Figure 7b), which were of variable size and shape. Scattered hemorrhage and extravasated RBC appeared in the area of necrosis due to the acute death of hepatocytes, which caused the collapse of the hepatocyte cords and overdilatation of the sinusoid. The extents of hepatic necrosis on day 1 were quantified as a percentage; viz., of necrotic area / total examined area, for which microscopic images were analyzed using ImageJ shareware (http://rsbweb.nih.gov/ij/). The data are presented in Table SI3. Without MBs, sections from tissues treated by US at 2.7 MPa PNP showed subtle necrosis ( $1 \%$ of total area of section examined). Combined with even low concentrations of MBs, the damage extent showed a considerable increase (6\%). Similarly, with $10 \mathrm{Vol} \%$ $\mathrm{MBs}$, increasing PNP increased the extent of hemorrhage and coagulative necrosis, particularly as observed near the treated surface. Sections from tissues treated at $2.0 \mathrm{MPa}$ showed an injury extent similar to that of tissues treated at $2.7 \mathrm{MPa}(\sim 10 \%)$, less than the one treated at $3.3 \mathrm{MPa}(\sim 15 \%)$, but more than that treated at $1.0 \mathrm{MPa}(\sim 4 \%)$, which is consistent with the PNP inflection point ( $2.0 \mathrm{MPa})$ suggested by the correlation of PNP and luciferase expression level (Figure 5).

Hepatic damage type and the pattern of tissue repair were similar in sections from all US treated rats. Coagulative necrosis was evident on day 1 , and was significantly diminished and revealed recovery on day 5 and later on (Figure 7c-e). On day 5, only a few foci of fibroblasts and lymphocytes infiltration were present around the portal area (Figure 7c). Damage was mostly repaired within 12 days and by day 30 these lobes showed no significant residual damage.

We also studied sections of liver lobes treated with the superior (from the perspective of gene expression and transaminase levels) US protocol involving $1 \mathrm{~s}$ 'on', $2 \mathrm{~s}$ 'off' pulsetrain US exposures at 2.7 MPA and $10 \mathrm{Vol} \%$ MBs. Tissues harvested on days 0 or 1 showed extents of hemorrhage and coagulative necrosis $(\sim 5 \%)$ significantly less than those in lobes 
treated with our 'standard' US protocol at 2.7 MPa PNP with 10 Vol\% MBs. Damage repair kinetics were similar to those described above.

\section{DISCUSSION}

US has been applied to various biological systems in attempts to enhance gene or drug delivery $^{9-11}$. We previously reported that US- and MB- mediated gene delivery of naked plasmids using a focused transducer system efficiently enhanced gene expression in murine livers via portal vein injection ${ }^{47-49}$. Although geometric focusing of the transducer enables large acoustic pressures to be realized with lower power equipment, it has the disadvantage that the focal 'spot' is small, and consequently, the tissue volume that can be treated at any instant in time is correspondingly small. The inability to treat relatively large tissue volumes with US during the period in which plasmids and MBs are present at high concentrations in the tissue could represent a significant impediment to applying the technology to larger animals in preclinical or clinical studies. The present study was undertaken to determine if an unfocused, broad-beamed US source capable of generating at least 2 MPa peak negative pressure and appropriate treatment protocols could be developed to enhance plasmid gene delivery in an animal of intermediate size; viz., the rat, in which the liver volume is $\sim 20$-fold greater than that of the mouse. The unfocused, $170 \mathrm{~mm}^{2}$ - footprint transducer (H158A) was developed. Gene and MB physical delivery protocols were also adjusted relative to those used in mice including the targeted injection and subsequent insonation of a specific lobe of the rat liver.

The H158A transducer was robust, able to generate high (>3 MPa) acoustic pressures over much of its surface without significant self-heating at the duty factors used here. It can treat much larger tissue volumes in less time and more evenly than can be achieved with a focused US source. In order to achieve targeted treatment, only the medial liver lobe was injected with plasmid and MBs as a specific target, and insonified. For targeted injection, a catheter was inserted into the portal venous branch through the portal vein and advanced towards the specific medial lobe to decrease surgical mechanical damage and improve the introduction of the plasmid/MB preparation. Injected plasmid dose was scaled up to $150 \mu \mathrm{g}$ in $1 \mathrm{ml}$ from the one used in mouse model $(50 \mu \mathrm{g}$ in $440 \mu \mathrm{l})$ according to the tissue volume ratio of the rat medial liver lobe and mouse liver as a whole. To avoid a hydrodynamic effect caused by high pressure during the injection, we also tested different injection rates and US treated times to obtain low-pressure fluid flow as well as efficient gene delivery. On the basis of these exploratory studies, the injection time was extended to $45 \mathrm{sec}$, and the acoustic time extended to $90 \mathrm{sec}$. Figure 3 shows that there was almost no gene expression in rats injected with plasmid/MBs only without US exposure, indicating that there was no hydrodynamic effect with our injection protocol. These modifications resulted in substantial and significant enhancement of US / MB-mediated reporter plasmid gene expression in the rat model system.

We previously evaluated gene expression of luciferase plasmid in mouse studies up to 7 days post treatment. Luciferase expression reached the maximum levels within 16-24 hours, and then dropped rapidly to very low levels in 7 days. The pGL4 plasmid driven by SV40 promoter cannot provide persistent gene expression in the liver. We thus used this reporter plasmid with high expression levels at 24 hours after treatment, instead of long-term effects, to optimize our ultrasound parameters and gene transfer protocols. It can be compared with other published research results by reference to the levels of luciferase reporter gene expression. For achieving persistent therapeutic gene expression in the future, we will use specific gene transfer vectors driven by a liver-specific promoter/enhancer with which longterm gene expression has been obtained ${ }^{51}$. 
The effect of Definity ${ }^{\circledR}$ MB concentration on gene transfer was explored in the rat model (Figure 4). US exposure parameters were also explored (Figure 5). The rat results are broadly similar to those obtained in the mouse in that gene expression displayed an upward trend with increment of MB dosages or acoustic PNP, and then gradually reached a plateau level. The apparent threshold MB concentration for a significant enhancement of gene expression was much lower than in prior mouse experiments (viz., 0.1 Vol\% (Figure 4), vs. $1.5 \mathrm{Vol} \%$ in mouse studies ${ }^{47}$ ). Even without MBs, at $2.7 \mathrm{MPa}$, \{plasmid + US \}-treated rats showed a significant enhancement of gene transfer relative to \{plasmid only\} treatment, a finding we never observed in our earlier mouse studies. Thus it appears possible that the 2.7 MPa US treatment may have been inducing 'spontaneous' cavitation in the blood or injectate, although the PNP we used was substantially less than the 4 MPa threshold (at 1 $\mathrm{MHz}$ ) predicted by $\mathrm{Church}^{50}$ for blood. Furthermore, in US-treated rats, a maximum level was observed at a MB concentration of $10 \mathrm{Vol} \%$, while in the mouse model, the peak was at $15 \mathrm{Vol} \%$. These differences were most likely due to more efficient acoustic exposure from the larger-footprint unfocused transducer used in the rat experiments. Acoustic pressure is a hinge parameter; transgene expression as well as liver damage correlated strongly with PNP. At less than $2.0 \mathrm{MPa}$, luciferase expression increased as PNP increased, indicating the induction of 'productive' damage which presumably increases extravasation of plasmid and accordingly promotes the gene transfer effect. At higher pressures, luciferase expression trended toward a plateau level while liver enzymes indicative of liver damage increased. This is consistent with the results from our earlier mouse studies, which indicated the involvement of an inertial cavitation mechanism and a relationship between gene expression and tissue damage induced by US exposure ${ }^{47}$.

The induction of some level of liver damage appears to be critical to the US and MBinduced increase in nonviral transgene expression we observe. Damage of treated liver lobes was assessed by transaminase assays and histology staining. However, transaminase values showed only transiently minor increases compared with untreated rats, but also only marginal differences between the US treated rats with various conditions, implying minimum functional damage from US/MBs treatment of one liver lobe. This is a significant technical improvement relative to our previous mouse study, in which US treatment showed a more pronounced liver functional damage denoted by much higher transaminase levels including ALT(50 1000 IU/L) and AST (100 700 IU/L) at day 1 post treatment.

We also investigated gene transfer effect of various inter-pulse periods, duty factors and pulse-train US exposure protocols. Our hypothesis was that longer quiescent periods between MB-destroying US pulses would increase gene transfer by allowing the tissues to refill with MBs between exposures, this was not the case. Application of the pulse-train US exposure at $13.9 \mathrm{~Hz}$ PRF showed a gene transfer efficiency that was broadly comparable with our 'standard' positive control conditions (Figure 6b) but produced less liver damage (Figure 7). However, these experiments were performed using $10 \mathrm{Vol} \%$ Definity concentrations, at which the peak gene expression was achieved. It is possible that MBs were saturating the acoustic field. We may be able to observe the "refilling" effect if lower MB concentrations will be used. Use of a higher PRF $(55.6 \mathrm{~Hz})$ pulse-train acoustic exposure enhanced gene expression to a level similar to that observed using the $13.9 \mathrm{~Hz}$ PRF, but resulted in more liver damage. The results obtained at the lower PRF suggest that with appropriate 'interrupted' acoustic treatment protocols, effective gene transfer can be achieved with lower total exposures to relatively high acoustic pressure, and that tissue damage can be kept at a low level.

Treatment-related liver damage was repaired by day 5 to day 30 after treatment. While the qualitative nature of the bioeffects was similar in all US-treated livers, the hepatic damage increased generally with increasing acoustic pressure at constant MB dose, or with 
increasing Definity ${ }^{\circledR}$ dose at constant pressure. Therefore, the most promising future approaches will likely involve relatively modest acoustic pressures (e.g., $2 \mathrm{MPa}$ ) and MB concentrations to achieve the greatest gene transduction benefit at the lowest practical tissue damage 'cost'.

In conclusion, the application of an unfocused US transducer which exposed a large tissue volume to reasonably uniform acoustic pressures in the near field, and targeted treatment achieved by both targeted acoustic exposure and lobe-specific injection protocols significantly enhanced the transgene efficiency of luciferase reporter plasmid in a rat model. The scale-up (from mouse to rat models) experiments represent a necessary milestone on the path toward the eventual goal of the safe and efficient application of US-assisted gene transfer methods in future clinical therapeutic applications.

\section{Supplementary Material}

Refer to Web version on PubMed Central for supplementary material.

\section{Acknowledgments}

This work was supported by R01 (R01 HL69049) and R21/33 (R33 HL089038) grants from NIH-NHLBI.

Meiling Chen provided help on liver histology evaluation in this paper.

\section{REFERENCES}

1. VandenDriessche T, Collen D, Chuah MK. Gene therapy for the hemophilias. J Thromb Haemost. 2003; 1(7):1550-1558. [PubMed: 12871290]

2. Niemeyer GP, Herzog RW, Mount J, Arruda VR, Tillson DM, Hathcock J, van Ginkel FW, High KA, Lothrop CD Jr. Long-term correction of inhibitor-prone hemophilia B dogs treated with liverdirected AAV2-mediated factor IX gene therapy. Blood. 2009; 113(4):797-806. [PubMed: 18957684]

3. Follenzi A, Battaglia M, Lombardo A, Annoni A, Roncarolo MG, Naldini L. Targeting lentiviral vector expression to hepatocytes limits transgene-specific immune response and establishes longterm expression of human antihemophilic factor IX in mice. Blood. 2004; 103(10):3700-3709. [PubMed: 14701690]

4. Yasuda M, Bishop DF, Fowkes M, Cheng SH, Gan L, Desnick RJ. AAV8-mediated gene therapy prevents induced biochemical attacks of acute intermittent porphyria and improves neuromotor function. Mol Ther. 2010; 18(1):17-22. [PubMed: 19861948]

5. Auman JT. Gene therapy: Have the risks associated with viral vectors been solved? Curr Opin Mol Ther. 2010; 12(6):637-638. [PubMed: 21280375]

6. Liras A, Olmedillas S. Gene therapy for haemophilia...yes, but...with non-viral vectors? Haemophilia. 2009; 15(3):811-816. [PubMed: 19432929]

7. Walther W, Stein U. Viral vectors for gene transfer: a review of their use in the treatment of human diseases. Drugs. 2000; 60(2):249-271. [PubMed: 10983732]

8. Niidome T, Huang L. Gene therapy progress and prospects: nonviral vectors. Gene Ther. 2002; 9(24):1647-1652. [PubMed: 12457277]

9. Duvshani-Eshet M, Baruch L, Kesselman E, Shimoni E, Machluf M. Therapeutic ultrasoundmediated DNA to cell and nucleus: bioeffects revealed by confocal and atomic force microscopy. Gene Ther. 2006; 13(2):163-172. [PubMed: 16177822]

10. Negishi Y, Omata D, Iijima H, Takabayashi Y, Suzuki K, Endo Y, Suzuki R, Maruyama K, Nomizu M, Aramaki Y. Enhanced laminin-derived peptide AG73-mediated liposomal gene transfer by bubble liposomes and ultrasound. Mol Pharm. 2010; 7(1):217-226. [PubMed: 20020739] 
11. Phillips LC, Klibanov AL, Wamhoff BR, Hossack JA. Targeted gene transfection from microbubbles into vascular smooth muscle cells using focused, ultrasound-mediated delivery. Ultrasound Med Biol. 2010; 36(9):1470-1480. [PubMed: 20800174]

12. Casey G, Cashman JP, Morrissey D, Whelan MC, Larkin JO, Soden DM, Tangney M, O'Sullivan GC. Sonoporation mediated immunogene therapy of solid tumors. Ultrasound Med Biol. 2010; 36(3):430-440. [PubMed: 20133039]

13. Guo H, Leung JC, Chan LY, Tsang AW, Lam MF, Lan HY, Lai KN. Ultrasound-contrast agent mediated naked gene delivery in the peritoneal cavity of adult rat. Gene Ther. 2007; 14(24):17121720. [PubMed: 17960163]

14. Sheyn D, Kimelman-Bleich N, Pelled G, Zilberman Y, Gazit D, Gazit Z. Ultrasound-based nonviral gene delivery induces bone formation in vivo. Gene Ther. 2008; 15(4):257-266. [PubMed: 18033309]

15. Suzuki R, Takizawa T, Negishi Y, Utoguchi N, Sawamura K, Tanaka K, Namai E, Oda Y, Matsumura Y, Maruyama K. Tumor specific ultrasound enhanced gene transfer in vivo with novel liposomal bubbles. J Control Release. 2008; 125(2):137-144. [PubMed: 18035442]

16. Watanabe Y, Aoi A, Horie S, Tomita N, Mori S, Morikawa H, Matsumura Y, Vassaux G, Kodama T. Low-intensity ultrasound and microbubbles enhance the antitumor effect of cisplatin. Cancer Sci. 2008; 99(12):2525-2531. [PubMed: 19018767]

17. Fechheimer M, Boylan JF, Parker S, Sisken JE, Patel GL, Zimmer SG. Transfection of mammalian cells with plasmid DNA by scrape loading and sonication loading. Proc Natl Acad Sci U S A. 1987; 84(23):8463-8467. [PubMed: 2446324]

18. Meijering BD, Juffermans LJ, van Wamel A, Henning RH, Zuhorn IS, Emmer M, Versteilen AM, Paulus WJ, van Gilst WH, Kooiman K, de Jong N, Musters RJ, Deelman LE, Kamp O. Ultrasound and microbubble-targeted delivery of macromolecules is regulated by induction of endocytosis and pore formation. Circ Res. 2009; 104(5):679-687. [PubMed: 19168443]

19. Bekeredjian R, Kroll RD, Fein E, Tinkov S, Coester C, Winter G, Katus HA, Kulaksiz H. Ultrasound targeted microbubble destruction increases capillary permeability in hepatomas. Ultrasound Med Biol. 2007; 33(10):1592-1598. [PubMed: 17618040]

20. Taniyama Y, Tachibana K, Hiraoka K, Namba T, Yamasaki K, Hashiya N, Aoki M, Ogihara T, Yasufumi K, Morishita R. Local delivery of plasmid DNA into rat carotid artery using ultrasound. Circulation. 2002; 105(10):1233-1239. [PubMed: 11889019]

21. Cochran SA, Prausnitz MR. Sonoluminescence as an indicator of cell membrane disruption by acoustic cavitation. Ultrasound Med Biol. 2001; 27(6):841-850. [PubMed: 11516544]

22. Guzman HR, Nguyen DX, Khan S, Prausnitz MR. Ultrasound-mediated disruption of cell membranes. II. Heterogeneous effects on cells. J Acoust Soc Am. 2001; 110(1):597-606. [PubMed: 11508985]

23. Wu J. Theoretical study on shear stress generated by microstreaming surrounding contrast agents attached to living cells. Ultrasound Med Biol. 2002; 28(1):125-129. [PubMed: 11879959]

24. van Wamel A, Kooiman K, Harteveld M, Emmer M, ten Cate FJ, Versluis M, de Jong N. Vibrating microbubbles poking individual cells: drug transfer into cells via sonoporation. J Control Release. 2006; 112(2):149-155. [PubMed: 16556469]

25. Miao, CH.; Brayman, AA. Yuan, X. Non-viral Gene Delivery. Intech: Rijeka, Croatia; 2011. Ultrasound-mediated Gene Delivery; p. 213-242.

26. Sakakima Y, Hayashi S, Yagi Y, Hayakawa A, Tachibana K, Nakao A. Gene therapy for hepatocellular carcinoma using sonoporation enhanced by contrast agents. Cancer Gene Ther. 2005; 12(11):884-889. [PubMed: 15891773]

27. Hosseinkhani H, Tabata Y. Ultrasound enhances in vivo tumor expression of plasmid DNA by PEG-introduced cationized dextran. J Control Release. 2005; 108(2-3):540-556. [PubMed: 16219383]

28. Hauff P, Seemann S, Reszka R, Schultze-Mosgau M, Reinhardt M, Buzasi T, Plath T, Rosewicz S, Schirner M. Evaluation of gas-filled microparticles and sonoporation as gene delivery system: feasibility study in rodent tumor models. Radiology. 2005; 236(2):572-578. [PubMed: 16040915] 
29. Bekeredjian R, Chen S, Grayburn PA, Shohet RV. Augmentation of cardiac protein delivery using ultrasound targeted microbubble destruction. Ultrasound Med Biol. 2005; 31(5):687-691. [PubMed: 15866418]

30. Kodama T, Tan PH, Offiah I, Partridge T, Cook T, George AJ, Blomley MJ. Delivery of oligodeoxynucleotides into human saphenous veins and the adjunct effect of ultrasound and microbubbles. Ultrasound Med Biol. 2005; 31(12):1683-1691. [PubMed: 16344130]

31. Korpanty G, Chen S, Shohet RV, Ding J, Yang B, Frenkel PA, Grayburn PA. Targeting of VEGFmediated angiogenesis to rat myocardium using ultrasonic destruction of microbubbles. Gene Ther. 2005; 12(17):1305-1312. [PubMed: 15829992]

32. Zen K, Okigaki M, Hosokawa Y, Adachi Y, Nozawa Y, Takamiya M, Tatsumi T, Urao N, Tateishi K, Takahashi T, Matsubara H. Myocardium-targeted delivery of endothelial progenitor cells by ultrasound-mediated microbubble destruction improves cardiac function via an angiogenic response. J Mol Cell Cardiol. 2006; 40(6):799-809. [PubMed: 16678200]

33. Huber PE, Mann MJ, Melo LG, Ehsan A, Kong D, Zhang L, Rezvani M, Peschke P, Jolesz F, Dzau VJ, Hynynen K. Focused ultrasound (HIFU) induces localized enhancement of reporter gene expression in rabbit carotid artery. Gene Ther. 2003; 10(18):1600-1607. [PubMed: 12907952]

34. Pislaru SV, Pislaru C, Kinnick RR, Singh R, Gulati R, Greenleaf JF, Simari RD. Optimization of ultrasound-mediated gene transfer: comparison of contrast agents and ultrasound modalities. Eur Heart J. 2003; 24(18):1690-1698. [PubMed: 14499233]

35. Taniyama Y, Tachibana K, Hiraoka K, Aoki M, Yamamoto S, Matsumoto K, Nakamura T, Ogihara T, Kaneda Y, Morishita R. Development of safe and efficient novel nonviral gene transfer using ultrasound: enhancement of transfection efficiency of naked plasmid DNA in skeletal muscle. Gene Ther. 2002; 9(6):372-380. [PubMed: 11960313]

36. Lu QL, Liang HD, Partridge T, Blomley MJ. Microbubble ultrasound improves the efficiency of gene transduction in skeletal muscle in vivo with reduced tissue damage. Gene Ther. 2003; 10(5): 396-405. [PubMed: 12601394]

37. Wang X, Liang HD, Dong B, Lu QL, Blomley MJ. Gene transfer with microbubble ultrasound and plasmid DNA into skeletal muscle of mice: comparison between commercially available microbubble contrast agents. Radiology. 2005; 237(1):224-229. [PubMed: 16081853]

38. Duvshani-Eshet M, Machluf M. Efficient transfection of tumors facilitated by longterm therapeutic ultrasound in combination with contrast agent: from in vitro to in vivo setting. Cancer Gene Ther. 2007; 14(3):306-315. [PubMed: 17218948]

39. Rahim A, Taylor SL, Bush NL, ter Haar GR, Bamber JC, Porter CD. Physical parameters affecting ultrasound/microbubble-mediated gene delivery efficiency in vitro. Ultrasound Med Biol. 2006; 32(8):1269-1279. [PubMed: 16875960]

40. Horie S, Watanabe Y, Chen R, Mori S, Matsumura Y, Kodama T. Development of localized gene delivery using a dual-intensity ultrasound system in the bladder. Ultrasound Med Biol. 2010; 36(11):1867-1875. [PubMed: 20870350]

41. Li T, Tachibana K, Kuroki M. Gene transfer with echo-enhanced contrast agents: comparison between Albunex, Optison, and Levovist in mice--initial results. Radiology. 2003; 229(2):423428. [PubMed: 14512507]

42. Meijering BD, Henning RH, Van Gilst WH, Gavrilovic I, Van Wamel A, Deelman LE. Optimization of ultrasound and microbubbles targeted gene delivery to cultured primary endothelial cells. J Drug Target. 2007; 15(10):664-671. [PubMed: 18041634]

43. Li HL, Zheng XZ, Wang HP, Li F, Wu Y, Du LF. Ultrasound-targeted microbubble destruction enhances AAV-mediated gene transfection in human RPE cells in vitro and rat retina in vivo. Gene Ther. 2009; 16(9):1146-1153. [PubMed: 19571889]

44. Qiu Y, Luo Y, Zhang Y, Cui W, Zhang D, Wu J, Zhang J, Tu J. The correlation between acoustic cavitation and sonoporation involved in ultrasound-mediated DNA transfection with polyethylenimine (PEI) in vitro. J Control Release. 2010; 145(1):40-48. [PubMed: 20398711]

45. Un K, Kawakami S, Suzuki R, Maruyama K, Yamashita F, Hashida M. Enhanced transfection efficiency into macrophages and dendritic cells by a combination method using mannosylated lipoplexes and bubble liposomes with ultrasound exposure. Hum Gene Ther. 2010; 21(1):65-74. [PubMed: 19719400] 
46. Stride E, Porter C, Prieto AG, Pankhurst Q. Enhancement of microbubble mediated gene delivery by simultaneous exposure to ultrasonic and magnetic fields. Ultrasound Med Biol. 2009; 35(5): 861-868. [PubMed: 19282096]

47. Song SX, Shen ZP, Chen L, Brayman AA, Miao CH. Explorations of high-intensity therapeutic ultrasound and microbubble-mediated gene delivery in mouse liver. Gene Ther. 2011; 18(10): 1006-1014. [PubMed: 21451579]

48. Shen ZP, Brayman AA, Chen L, Miao CH. Ultrasound with microbubbles enhances gene expression of plasmid DNA in the liver via intraportal delivery. Gene Ther. 2008; 15(16):11471155. [PubMed: 18385766]

49. Miao CH, Brayman AA, Loeb KR, Ye P, Zhou L, Mourad P, Crum LA. Ultrasound enhances gene delivery of human factor IX plasmid. Hum Gene Ther. 2005; 16(7):893-905. [PubMed: 16000070]

50. Church CC. Spontaneous homogeneous nucleation, inertial cavitation and the safety of diagnostic ultrasound. Ultrasound Med Biol. 2002; 28(10):1349-1364. [PubMed: 12467862]

51. Miao CH, Thompson AR, Loeb K, Ye X. Long-term and therapeutic-level hepatic gene expression of human factor IX after naked plasmid transfer in vivo. Mol Ther. 2001; 3(6):947-957. [PubMed: 11407909] 


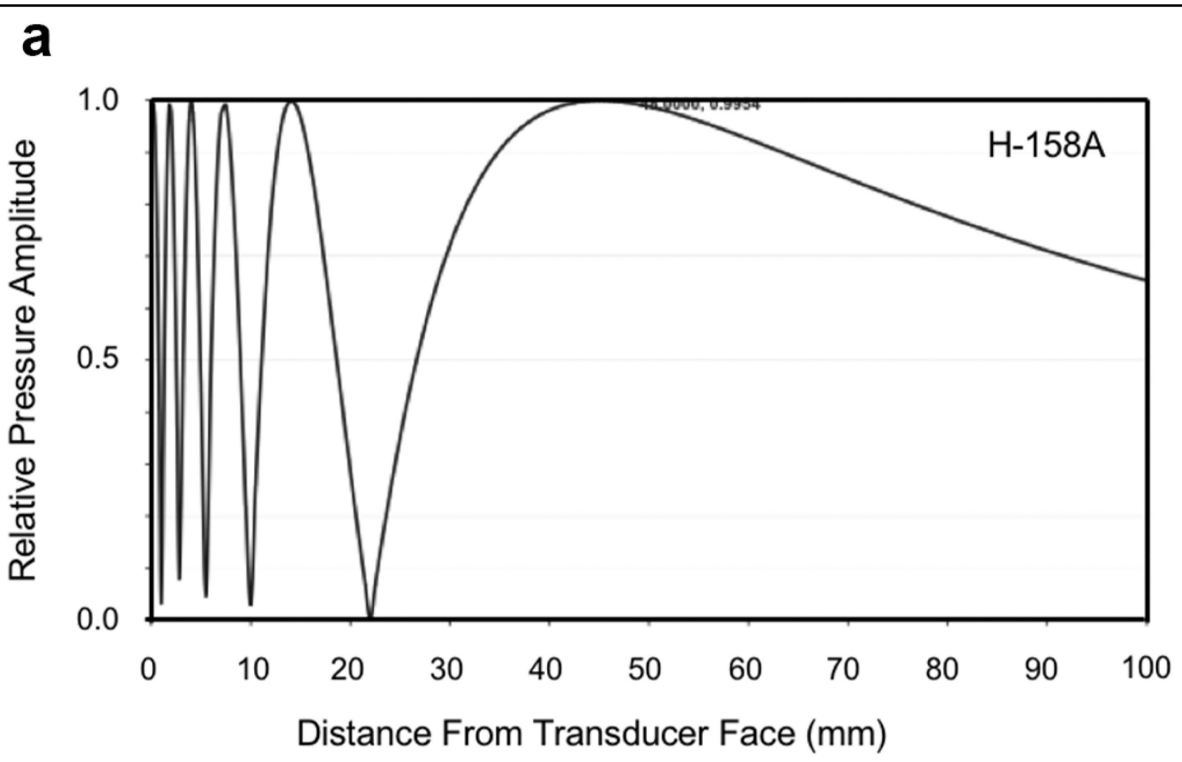

b

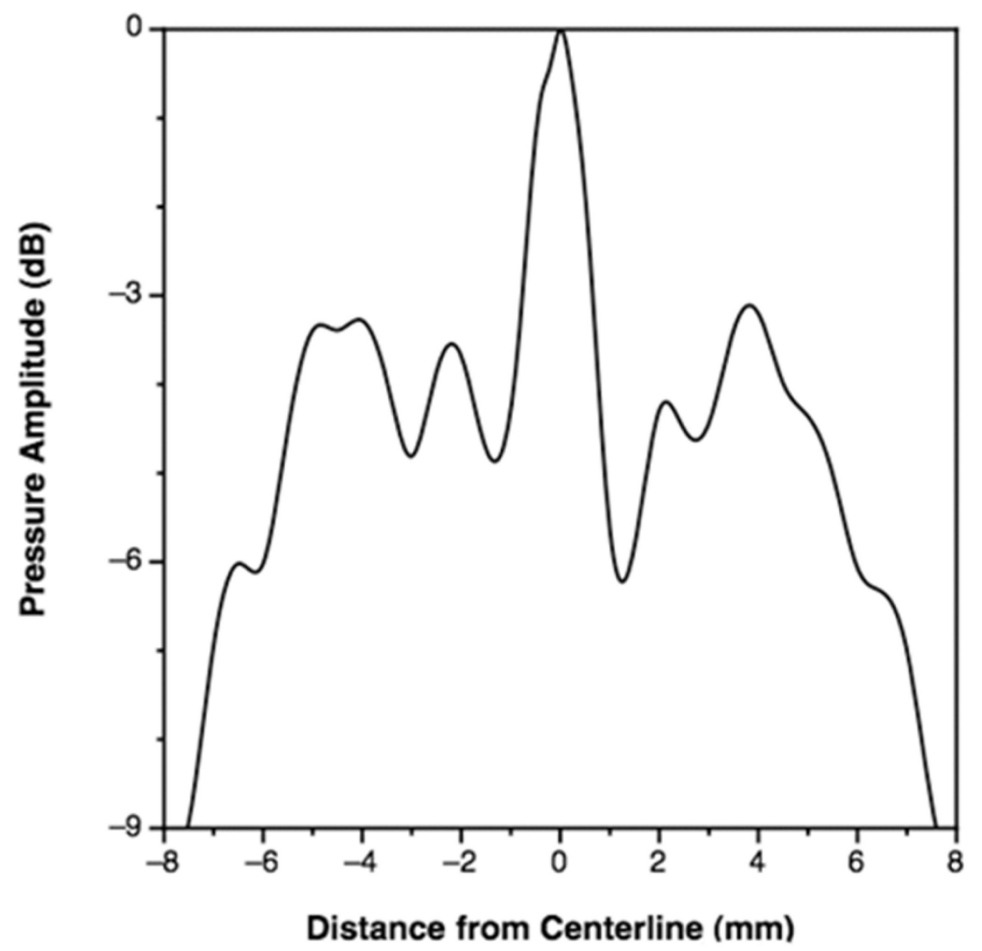

Figure 1. Acoustic pressure profiles of the H-158A unfocused H158A transducer in the near field (a) Axial acoustic pressure profile. For treatment of livers, the acoustic path through the organ is on the order of $3-5 \mathrm{~mm}$; the axial profile shows that the pressure amplitude goes through about 3 maxima and minima in the first $\sim 5 \mathrm{~mm}$ from the transducer face. (b) Transaxial pressure profiles. The near field profile was measured as close as practically possible to the transducer face, and represents a tomographic section located $6.2 \mathrm{~mm}$ from the emitting surface as assessed by time-of-flight of the sound waves. A high level of structure is seen, with annular rings of higher or lower pressure 'populating' a central pseudo-plateau about $10 \mathrm{~mm}$ wide if defined by the coordinates at which the sharp peripheral roll-off began, or $12 \mathrm{~mm}$ wide if defined by the full width, half maximum 
pressure beam diameter at this transaxial plane. A narrow peak of $\sim 2 \mathrm{~mm}$ diameter $(\sim 0.03$ $\mathrm{cm}^{2}$ ) is present at the center of this profile; this represents a very small fraction of the total radiating area. However, cavitation phenomena are influenced by peak pressure values, and the transducer was not stationary when applied to the rat livers, so some parts of the liver were exposed to peak pressures considerably larger than the spatial average value within the half maximum, full width beam diameter. 


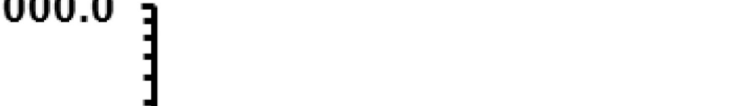

Transducer

Amplifier

Inj. route
Focused

ENI

Portal

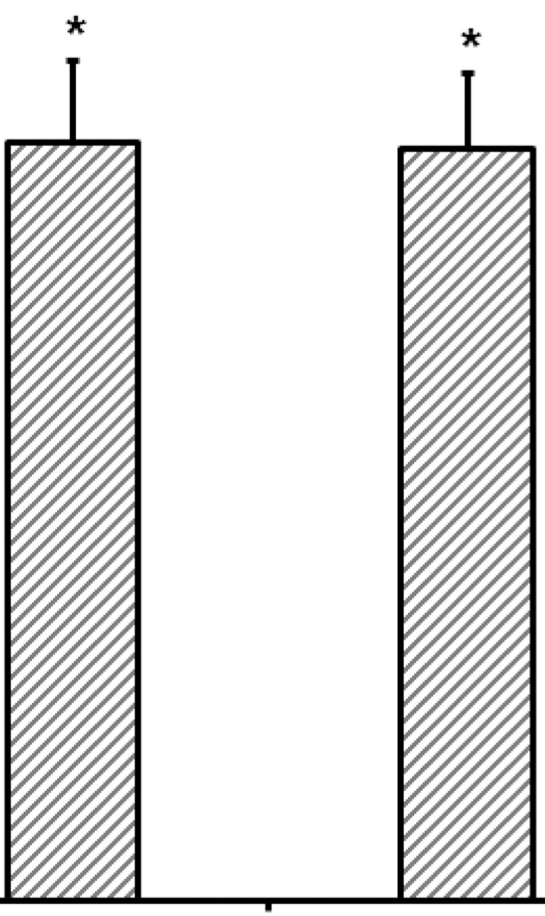

Unfocused

RFG

Portal branch

Figure 2. Enhancement of luciferase expression via portal vein or portal branch injection mediated by ultrasound treatment using focused or unfocused near-field transducers 150ug plasmid mixed with $15 \mathrm{Vol} \%$ Definity® was injected for $45 \mathrm{sec}$ with initially coincident acoustic exposure for $90 \mathrm{sec}$ using two different transducers and amplifers (focused and unfocused tranducer; ENI AP400B amplifier or RFG-1000 amplifier) as indicated. Gene expression enhancement ratios (US treated group injected with plasmid and Definity® vs. negative control group injected with plasmid and Definity® without US treatment) was compared. Comparably higher expression levels were obtained with unfocused transducer driven by either amplifier, whereas focused transducer produced much lower expression levels. Error bars indicate SEM $(n=8)$. 


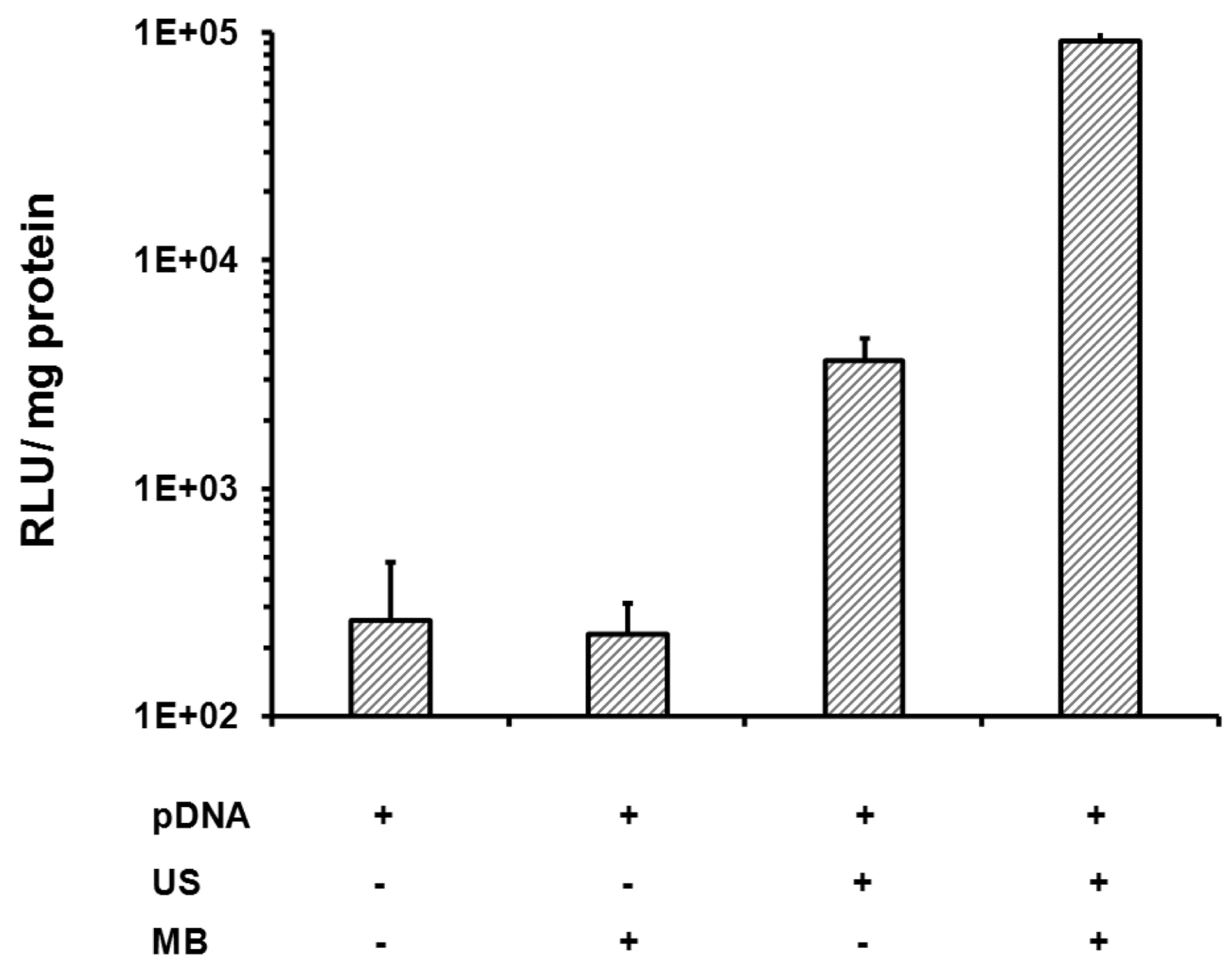

Figure 3. Gene expression enhanced by ultrasound (US) with microbubbles (MBs)

$150 \mu \mathrm{g}$ pGL4 mixed with $10 \mathrm{Vol} \%$ or sham Definity® was injected through a portal vein branch into the medial lobe of rat liver for $45 \mathrm{sec}$, with initially coincident or sham US exposure (1.1 MHz, 2.7 MPa peak negative pressure, 20 cycle pulses, $13.9 \mathrm{~Hz}$ PRF), which continued after injection for a total acoustic exposure time of $90 \mathrm{sec}$. Luciferase expression was measured in extracts from the treated lobe. Error bars indicate SEM ( $\mathrm{n}=6)$. 


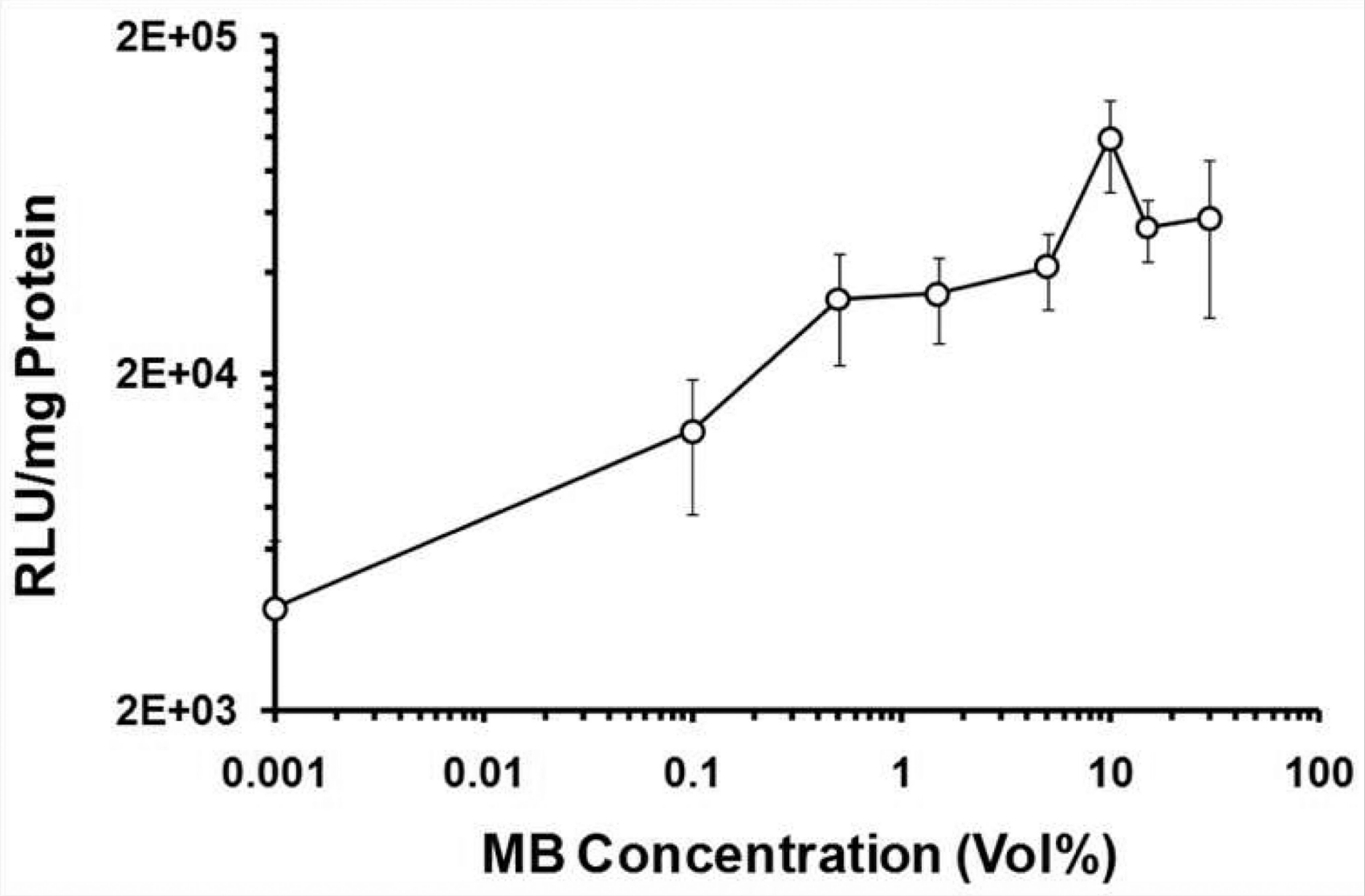

Figure 4. Dependence of transgene expression on Definity ${ }^{\circledR}$ concentrations mediated by US exposure with simultaneous injection of pDNA + MB mixture via portal vein branch Different concentrations of Definity ${ }^{\circledR}(\mathrm{Vol} \%$ : 0 30\%) were employed for gene delivery under the US exposure conditions of 1.1 MHz frequency, 2.7 MPa peak negative pressure, 20 cycle pulses, $13.9 \mathrm{~Hz}$ PRF, and $90 \mathrm{~s}$ total US exposure, the first $45 \mathrm{~s}$ of which were coincident with injection of pDNA and Definity®. In order to present the Definity ${ }^{\circledR}$ concentrations on a log scale (to better resolve the data at low Definity® concentrations), the true $0 \mathrm{Vol} \%$ Definity® data are plotted at an arbitrarily small value $(0.001 \mathrm{Vol} \%)$ concentration as a graphic expedience. Error bars indicate the standard error of the mean $(n=6)$. 


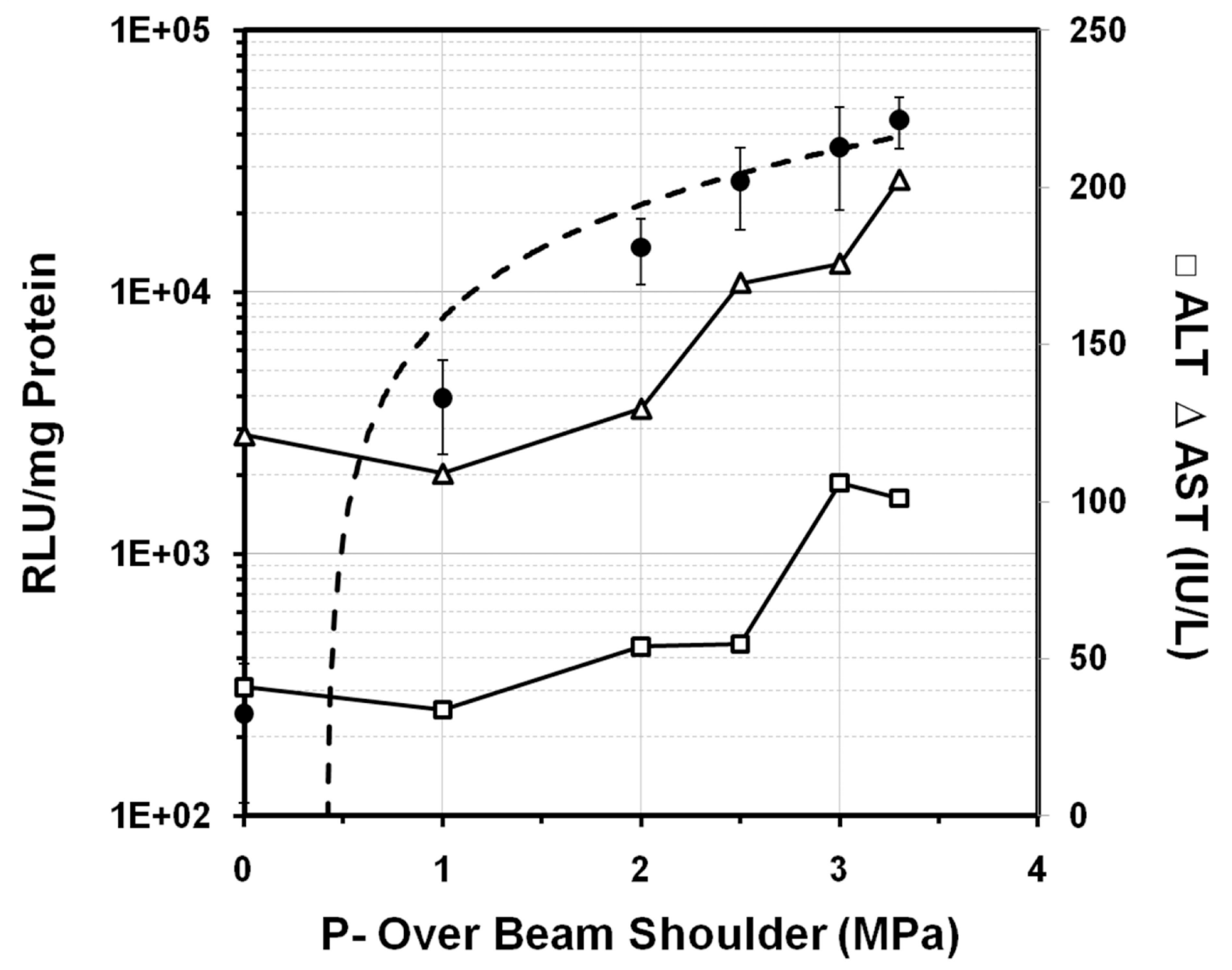

Figure 5. The effect of US peak negative pressure on gene transfer efficiency of luciferase plasmid with MBs injected through portal vein branch and correlation between luciferase expression of treated lobe and aminotransferase levels (ALT \& AST)

US exposure was performed on the medial lobe of rat liver under various acoustic negative pressures of 0-3.3 MPa peak negative pressure (1.1 MHz, 20 cycle pulses, 13.9 Hz PRF, and $90 \mathrm{sec}$ total exposure, the first $45 \mathrm{sec}$ of which were coincident with injection of $150 \mu \mathrm{g}$ pGL4 and 15 Vol\% Definity® toward median lobe). Closed circles and left vertical axis: Luciferase expression. Open symbols and right vertical axis: Liver damage produced by US exposure was assessed by alanine transaminase (ALT; open squares) and aspartate transaminase (AST; open triangles) levels with plasma collected at 24 hours after treatment. Error bars indicate SEM ( $n=7-9)$. 


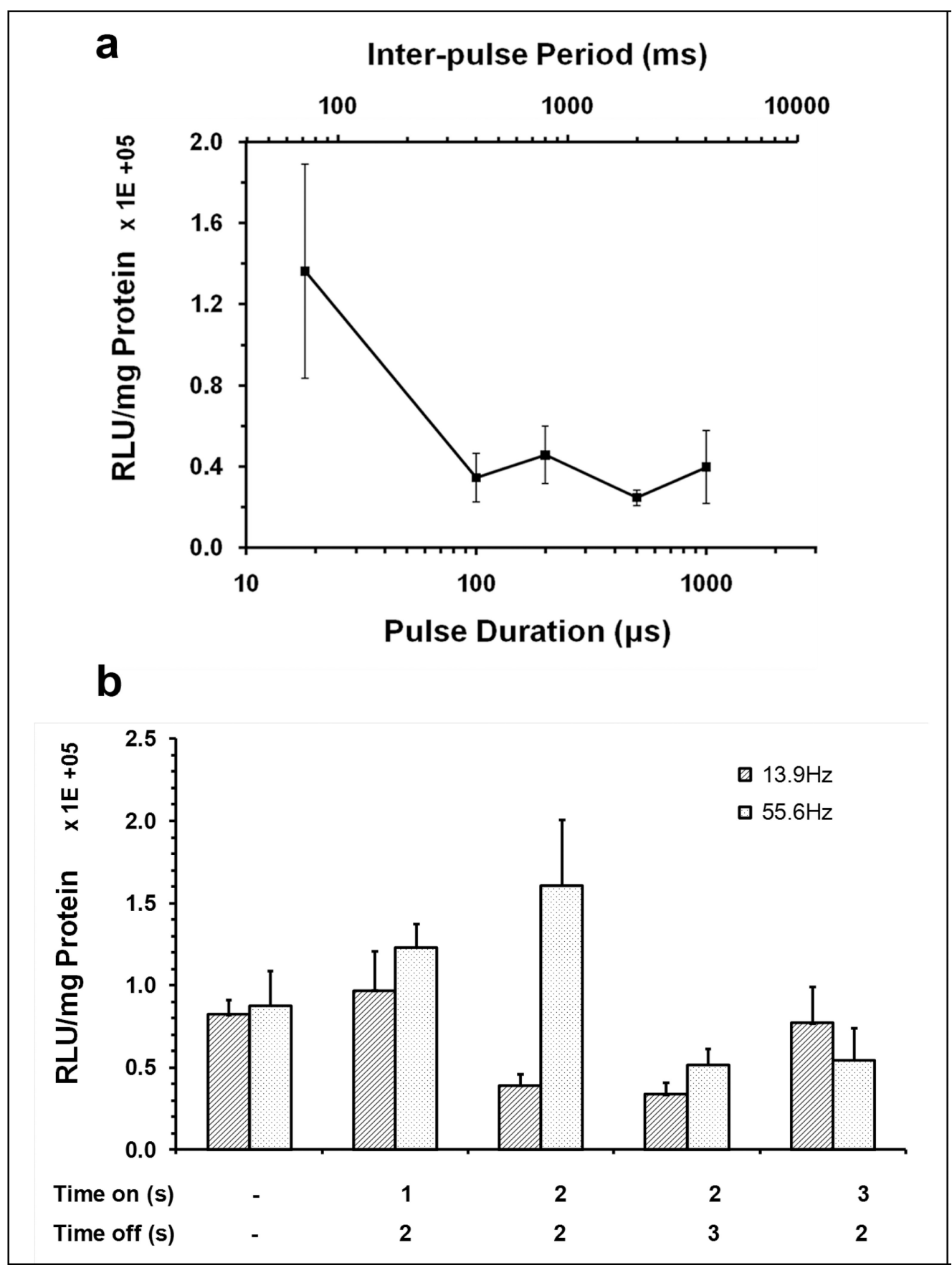

Figure 6. Effect of increased quiescent duration between US pulses on gene transfer efficiency (a) Effect of acoustic pulse durations on gene delivery. US exposure were performed on medial liver lobe for $90 \mathrm{sec}$, the first $45 \mathrm{~s}$ of which was coincident with injection of $150 \mu \mathrm{g}$ pGL4 plasmid and 15 Vol\% Definity® mixture into medial lobe. The acoustic exposure conditions with various inter-pulse periods from $72-4000 \mathrm{~ms}$ (upper axis) and corresponding pulse durations (lower axis) from 18 1000 $\mu$ s were 1.1 MHz, 2.7 MPa peak negative pressure, 0.00025 Duty Factor. Luciferase expression was measured on the treated median lobe. (b) Effect of pulse-train US exposure on gene delivery. US exposure was performed using either continuous bursts of 20 cycle pulses repeated at 13.9 or $55.6 \mathrm{~Hz} \mathrm{PRF}$ for $90 \mathrm{~s}$, or 1, 2 or $3 \mathrm{~s}$ exposures to bursts of pulsed US (on), interleafed by quiescent periods 
of 2 or $3 \mathrm{~s} \mathrm{(off).} \mathrm{The} \mathrm{detailed} \mathrm{parameters} \mathrm{were} \mathrm{shown} \mathrm{in} \mathrm{Table} 2$ (lower panel). All groups were treated by $90 \mathrm{~s}$ US exposures with simultaneous $45 \mathrm{~s}$ injection of plasmid/MBs via the portal branch toward the hepatic median lobe. Luciferase expression was measured on the treated liver lobe. Error bars indicate SEM ( $\mathrm{n}=6-7)$. 


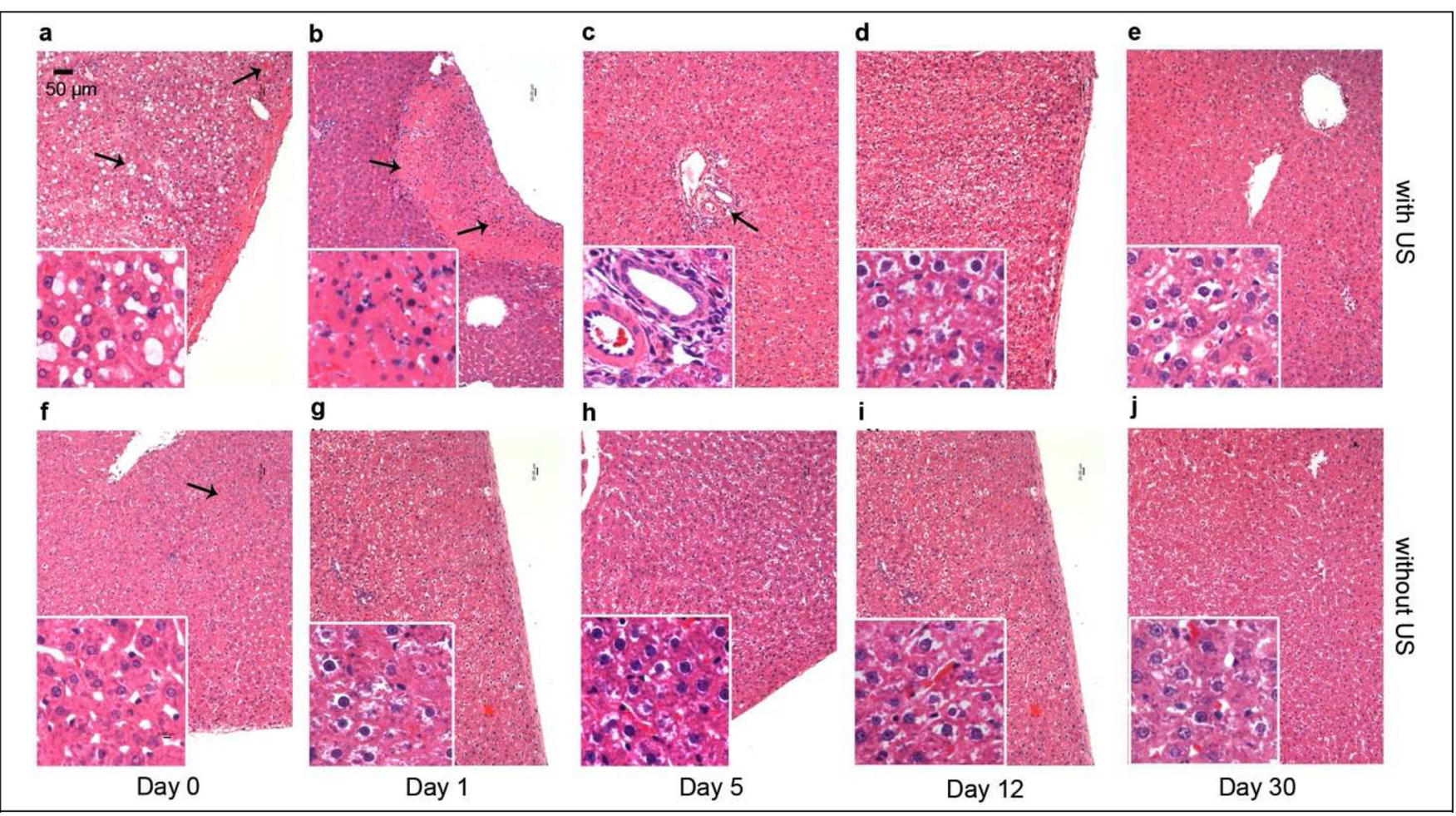

Figure 7.

Comparison of the histology features of rat livers injected with pDNA and MB via portal vein and simultaneously treated with (a-e) and without (f-j) $2.7 \mathrm{MPa}$ US exposure. The livers were harvested on day $0,1,5,12,30$ after treatment for H\&E staining. Original magnification X100, X400 in inserts. Scale bar $=50 \mu \mathrm{m}$. 


\section{Table 1}

Comparison of characteristics between the focused transducer used in our previous murine gene transfer and the unfocused H158 transducer built for use in the present study.

\begin{tabular}{llll}
\hline Transducer & $\begin{array}{l}\text { Electrical power for } \\
\text { desired acoustic pressure }\end{array}$ & $\begin{array}{l}\text { 'Acoustic } \\
\text { Footprint' }\end{array}$ & $\begin{array}{l}\text { Full width half maximum } \\
\text { pressure beam diameter }\end{array}$ \\
\hline Focused & $\sim 60$ Watts & $\sim 7.3 \mathrm{~mm}^{2}$ & $\sim 2.7 \mathrm{~mm}$ \\
Unfocused & $\sim 350$ Watts & $\sim 170 \mathrm{~mm}^{2}$ & $\sim 13.0 \mathrm{~mm}$ \\
\hline
\end{tabular}




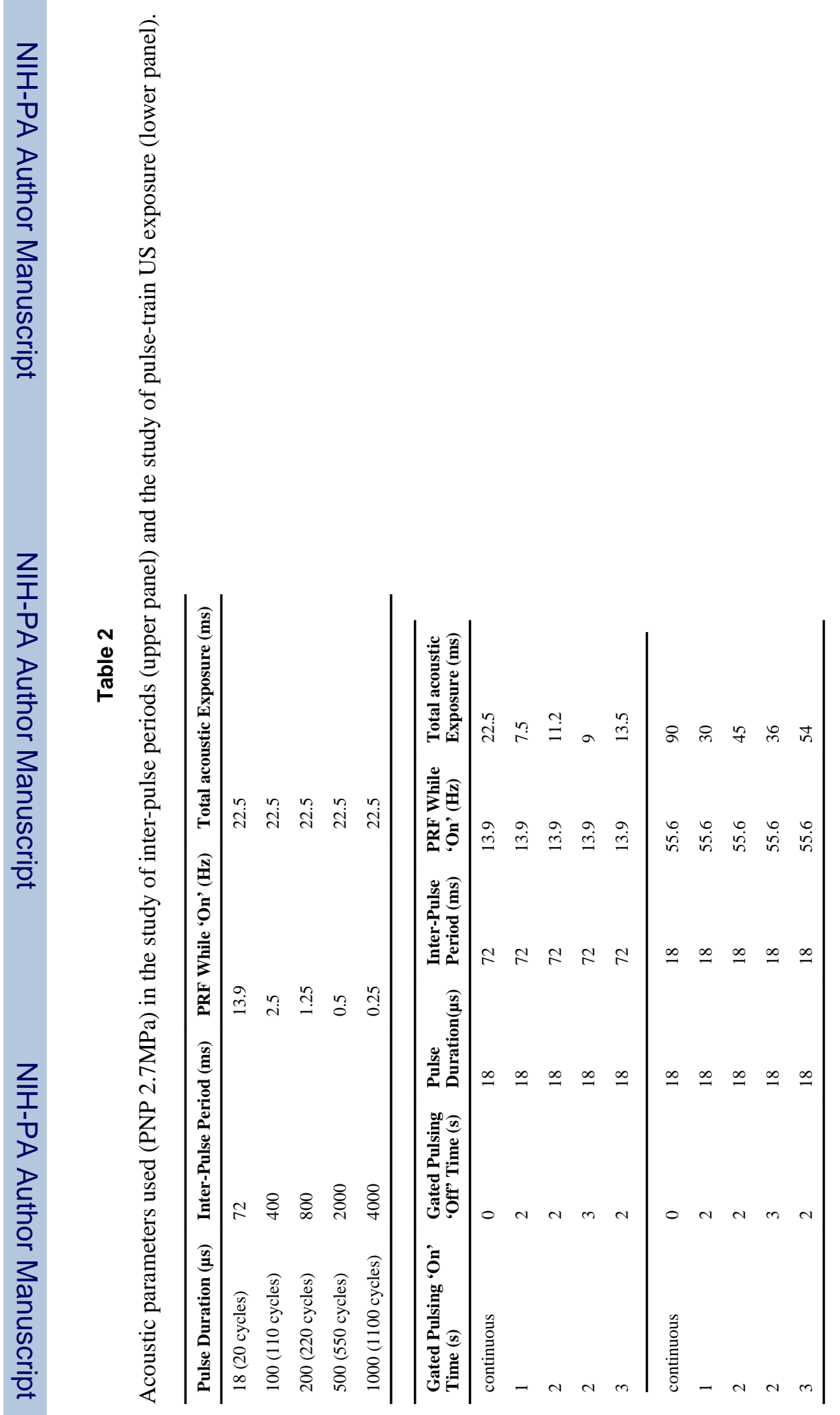

Mol Pharm. Author manuscript; available in PMC 2014 January 25. 